\title{
THE LEVEL OF CONSUMERS' INCOME AND THE DEVELOPMENT AND STRUCTURE OF RETAIL TRADE ON THE EXAMPLE OF WIELKOPOLSKIE AND PODLASKIE REGIONS
}

\author{
Andrzej KONDEJ ${ }^{1 *}$, Wiesław CIECHOMSKI ${ }^{2}$ \\ ${ }^{1}$ University in Białystok; andrzej.kondej@uwb.edu.pl, ORCID: 0000-0002-8979-3590 \\ ${ }^{2}$ University of Economics in Poznań; w.ciechomski@ue.poznan.pl, ORCID: 0000-0002-2310-8378 \\ * Correspondence author
}

Purpose: The paper explores the relationship between income factors and development parameters and the retail structure of the FMCG retail industry. The authors discussed the situation in retail trade in the years 2015-2019 and the evolution of disposable income and expenditure on food and soft drinks. A key part of the work takes into account the impact of income factors on consumer purchasing decisions in terms of choosing the place of shopping.

Design/methodology/approach: The study utilises the results of the author's multi-annual quantitative surveys of the retail market based on available industry sources. The statistical data on income and food expenditure developments and the results of available market research were also contributed. Pearson's linear correlation method was used to analyse the relationship between the dynamics of income factors and selected retail parameters, as well.

Findings: As a result of the studies and analyses carried out, it was found that the level of revenue mainly affects the product structure of purchases, but has a limited impact on the place of purchase and, consequently, on the structure of the retail trade. Consumers' decisions are based on several different factors (including non-income ones) and most commercial operators seek to address their offer to the widest possible range of shoppers.

Originality/value: The analyzes show that income factors exert a comprehensive but not directly impact on the situation in retail trade. There is no doubt that the steady long-term increase in consumer income is the basis for the development of commercial enterprises. Despite the steady increase in the level of affluence, the vast majority of Polish consumers still combine quality requirements with restrictions on household budgets. As a consequence, it favours the formation of a multi-format structure in retail trade in Poland, as various stores are able to meet the needs of the majority of Polish consumers.

Keywords: disposable income, expenditures on food, retail trade.

Category of the paper: Research paper. 


\section{Introduction}

The aim of this study is to determine the impact of income factors on the development and structure of retail trade in the FMCG sector in Poland. Due to the volume restrictions of the article, however, the considerations were limited to the regions of Wielkopolskie and Podlaskie voivodeships. Contemporary consumers are increasingly aware and have a comprehensive knowledge of the broadly understood commercial offer on the market. For this reason, it is the purchasing behaviour of consumers that must be taken into account to a large extent in management decisions made by trade managers. This will result in effective development strategies, which in the scale of the overall market shape a specific structure of retail trade of the fast-moving products.

Consumers' purchasing behaviour has a varied background, including: social, psychological, ecological and economic. The key economic factor is the level of disposable income that can be used for consumption, savings and other life purposes. The level of obtained income may shape diversified purchasing attitudes, as consumers display a spectrum of different needs and market behaviour. Moreover, decisions regarding the choice of a retail outlet and the purchase of specific products are determined by a wider set of human needs, which means that the income aspect is most often combined with other factors of influence.

This study covers the development and structure of the retail food trade, within which stores of various formats operated domestically. The retail in Poland is very diverse and competitive, which means that its concentration level is increasing and the inter-format structure is changing (Ciechomski, 2015, p. 108). Due to their development potential, many retail chains exceed the growth rate of the market as a whole. Hence, the development of stronger commercial entities takes place at the expense of economically weaker ones. Consumers who make autonomous purchasing decisions about the place of purchase have a significant impact on the success of these activities.

\section{Consumers' income and food expenses}

According to the theory of consumption, the most important factor shaping the structure of household expenditure is the level of individual income. The financial resources shape consumers' lifestyles and social attitudes, and therefore the income factor is related to sociocultural, environmental and psychological conditions. The economic determinants include prices, promotional activities, access to sources of financing, savings and, above all, disposable income (Liczmańska, 2015, p. 108). 
This part of the discussion focuses on the different decisions of consumers concerning the choice of where to make purchases. This is manifested in the application of diversified criteria for the selection of retail stores where fast-rotating goods are purchased.

The choice of place of purchase is made by individual consumers based on a set of criteria, which can additionally be variable over time. It manifests itself in the application of various criteria for selecting retail stores, in which purchases of fast-moving goods are made.

The result of this approach is the so-called mixed purchasing model used by a significant part of Polish consumers who visit various grocery stores according to their needs. The increasing access of consumers to knowledge, including m.in. via the internet, has led to the emergence of the phenomenon of smart shopping, which means making well-thought-out purchasing decisions. This attitude leads to obtaining the maximum benefit in terms essential for buyers (Sobczyk, 2013, pp. 118-119). In the retail market, the main manifestation of a smart shopping attitude is the desire for consumers to obtain as low prices as possible concerning the selected brands and specific products sought.

During the period of economic growth in 2015-2019, there was observable significant increase in annual average disposable income per capita. This phenomenon was accompanied by a constant improvement in consumer sentiment, which should have a positive impact on both the volume of purchases and the changing structure of consumption. This is confirmed by the research on consumer behaviour carried out by the end of 2019, which showed that the aspect of product quality was mentioned more often than the price level. The increase in consumer demand is largely the result of improved incomes for the lowest-paid groups. This is confirmed by indicators of poverty, the level of which has decreased significantly during the analysis period. This phenomenon is derived from economic growth, in particular the raising of the minimum wage, the Family 500+ program or the fall in unemployment.

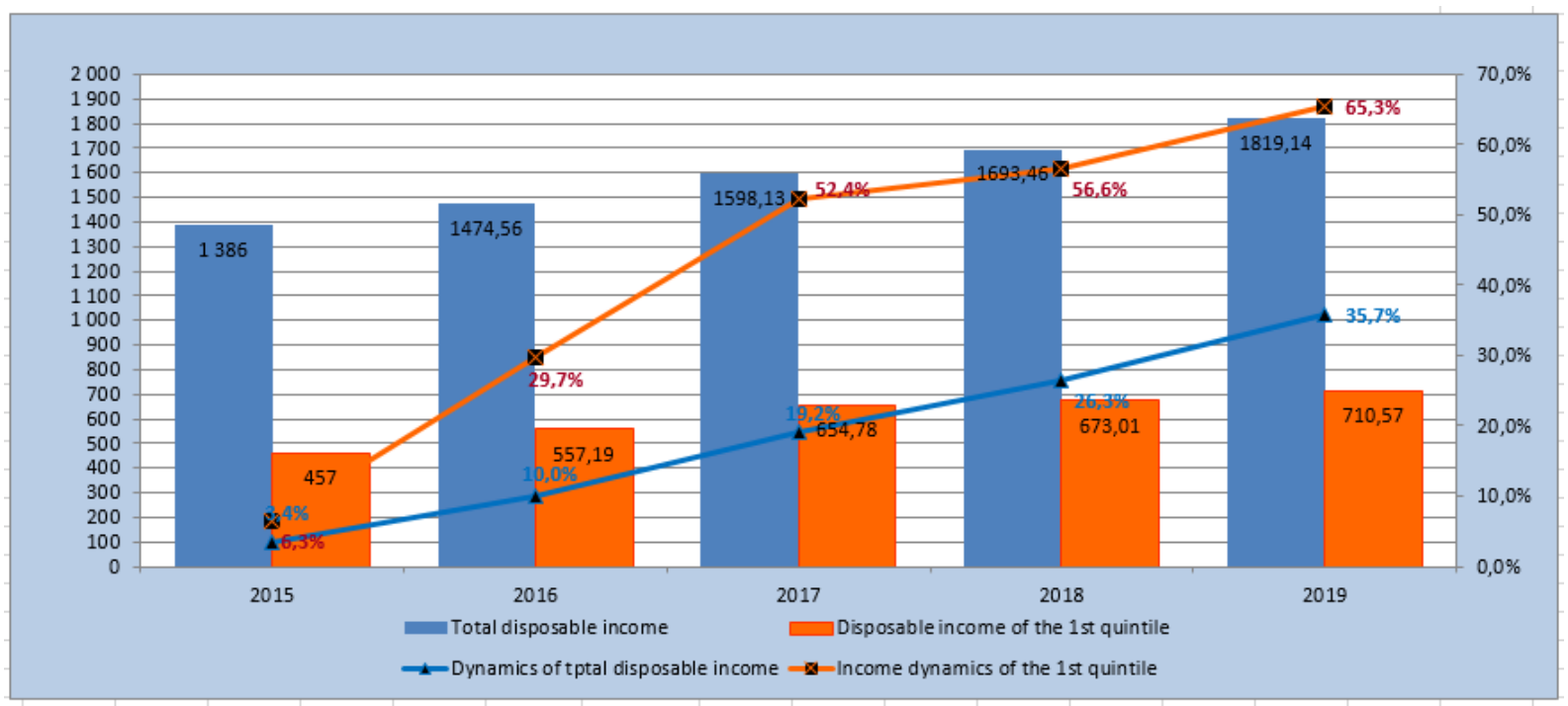

Figure 1. Total disposable income and quintile I in 2015-2019. Source: Own elaboration based on the research results. 
The strong increase in income of the group of the least well-off consumers is confirmed by the analysis of consumers belonging to the first quintile, whose disposable income in the analysis period 2015-2019 increased by 55.5\%, compared with an increase of the fifth quintile (20\% of the most well-off) of almost twice as much (23.6\%). Changes in the level of disposable income are illustrated in figure 1, which clearly shows a distinct indicator of the income dynamics of the least affluent people. This resulted in a decrease in the level of income differentiation expressed by the quintile coefficient of 4.9 in 2019, which is significantly lower than the level of 6.2 in 2015.

During the analysis period, there was a noticeable increase in spending on food and soft drinks at an average annual CAGR of $4.6 \%$ (Borusiak, 2008). It is easy to see that this increase is, however, significantly lower than the increase in disposable income during this period of $7.0 \%$. This means that the share of food and non-alcoholic beverage expenditure in disposable income is decreasing, from $18.9 \%$ in 2015 to a ceiling of $17.3 \%$ in 2019 . Figure 2 shows the downward trend of this indicator in 2015-2019. It is worth adding that this is a long-term trend that has been going on in Poland since 2005. This process means that consumer income growth is less than previously spent on food and other necessities, or rather spent on higherorder products, durable goods or consumer services, e.g. catering, tourism, entertainment (Gardocka-Jałowiec, 2015, p.198).

The low and ever-decreasing share of food expenditure as incomes increase means that the disparity between extreme groups of consumers is flattened. It follows that expenditure on food and soft drinks by the wealthiest consumers is only $60 \mathrm{pp}$ higher than that of those in the lowest income segment. This difference is therefore incomparably lower than the almost fivefold spread of income of similar groups of consumers.

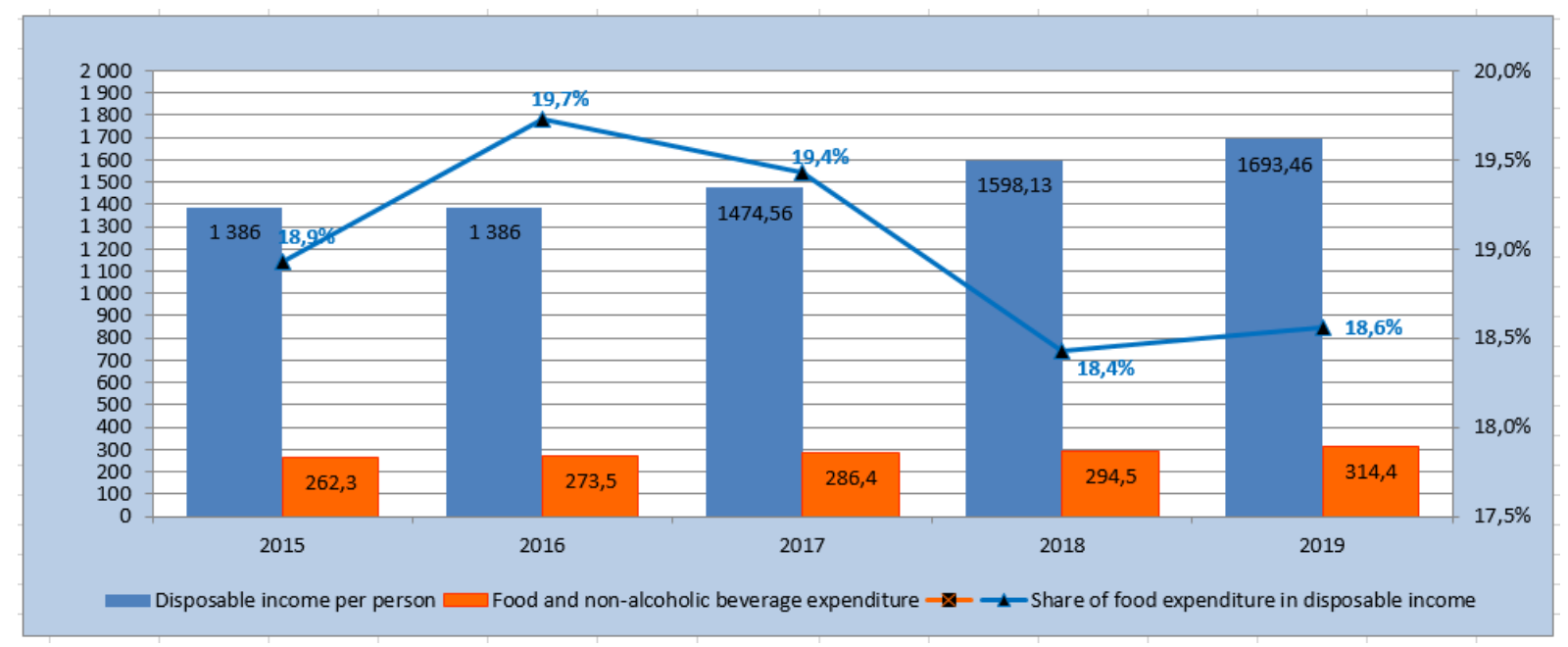

Figure 2. Share of food and non-alcoholic beverage expenditure in disposable income in 2015-2019 (in \%). Source: own elaboration based on the research results. 


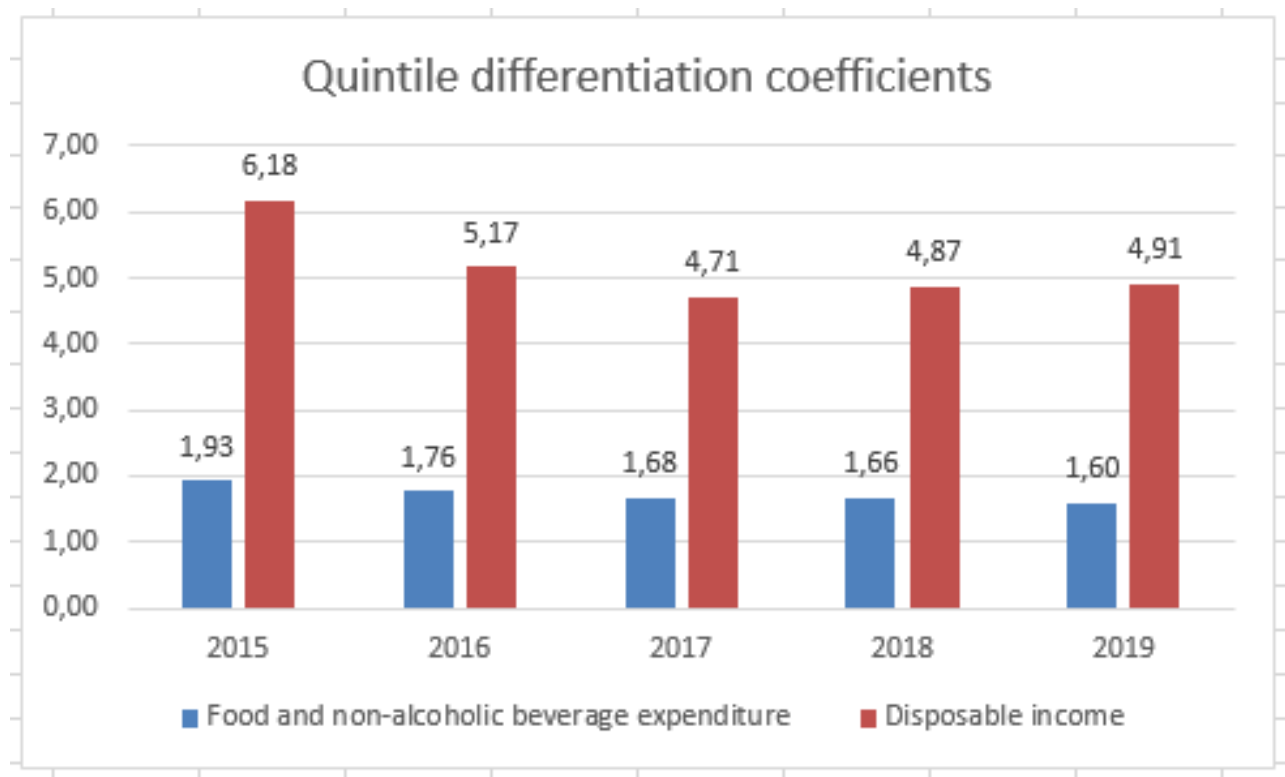

Figure 3. Rates of differentiation of expenditure on food and non-alcoholic beverages and disposable income. Source: own elaboration based on the research results.

Based on the data presented in Figure 3, it can be concluded that consumers with different income groups may display less and less differentiated purchasing behavior.

\section{Impact of income factors on the structure of retail trade in the years 2015-2019}

The inference on the impact of the level of wealth on the development and structure of the food market was made on the basis of a comparison of the dynamics of phenomena using deduction and synthesis methods, including using Pearson's linear Correlation index. Comparing the dynamics of these phenomena in the years 2015-2019 shows a very high level of compatibility of these phenomena, and only a slightly lower correlation occurs between the dynamics of income and the increase in the total sales area, which showed a slower pace during this period. The reverse correlation between the increase in revenue and the decrease in the number of shops only indicates that the Polish market is undergoing structural changes with positive growth parameters, i.e. more efficient stores replace the weakest retail units (Kondej, 2017a, pp. 124-125). Figure 4 shows the correlation indicators between consumers' disposable incomes and selected parameters for the development of trade in food products. 


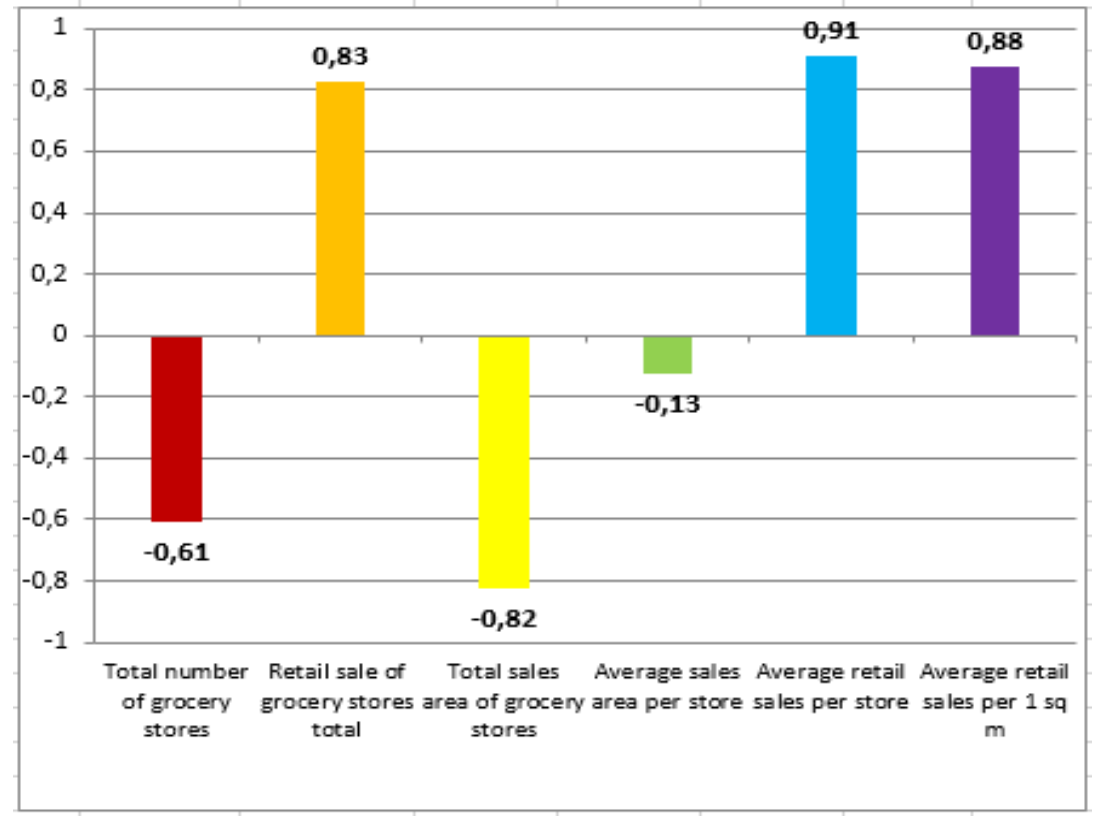

Figure 4. Correlation of disposable income with parameters of development of grocery stores (for the period 2015-2019). Source: own elaboration based on the research results.

A negative correlation index (-0.82) occurs between the growth rate of disposable income and the minimum dynamics of the total sales area. On the other hand, the highest level of correlation (0.91) concerns the average sales per store, which is mainly the result of a significant improvement in the effectiveness of retail trade, measured by the growing level of sales per $1 \mathrm{~m}^{2}$. Similarly, a high level of correlation appears between the dynamics of food and non-alcoholic beverage expenditure and the growth parameters of food retail stores, which is presented in Figure 5.

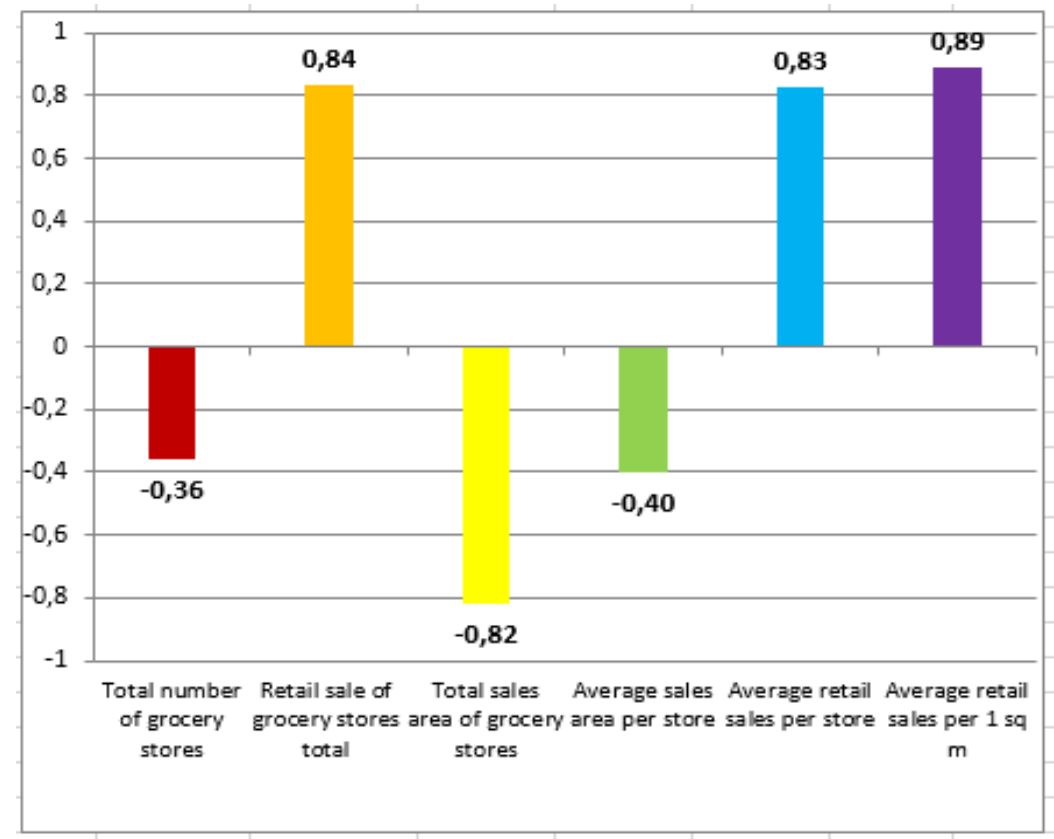

Figure 5. Correlation of food expenditure with the development parameters of grocery stores (for the period 2015-2019). Source: own elaboration based on the research results. 
In this context, high correlation indicators relate to the dynamics of expenditure on food and non-alcoholic beverages with retail sales of food trade ( 0.84$)$, average sales per store $(0.83)$ and average sales per $1 \mathrm{~m}^{2}(0,89)$. Negative indicators with regard to the total number of stores, total sales space and average sales space confirm the growth of the food market on the basis of increasing sales efficiency, including better use of available sales space.

It should also be noted that the growth rate of disposable income is much higher than the corresponding retail sales index in the food market. When applying these comparisons, however, it should be remembered that the level of disposable income creates only the potential for the development of retail trade, and the real value of the market is determined by the level of expenditure on basic products. Figure 6 below illustrates three economic categories, namely the dynamics of disposable income, expenditure on food purchases and the level of retail sales of grocery stores.

Due to the rapid increase in incomes of consumers with lower levels of wealth, their spending on food and other products of current consumption has increased rapidly. This has had a significant impact on retail sales, as such consumers spend a relatively large proportion of their income on food and necessities than the more affluent ones (Kuśmierczyk, 2012, p. 61).

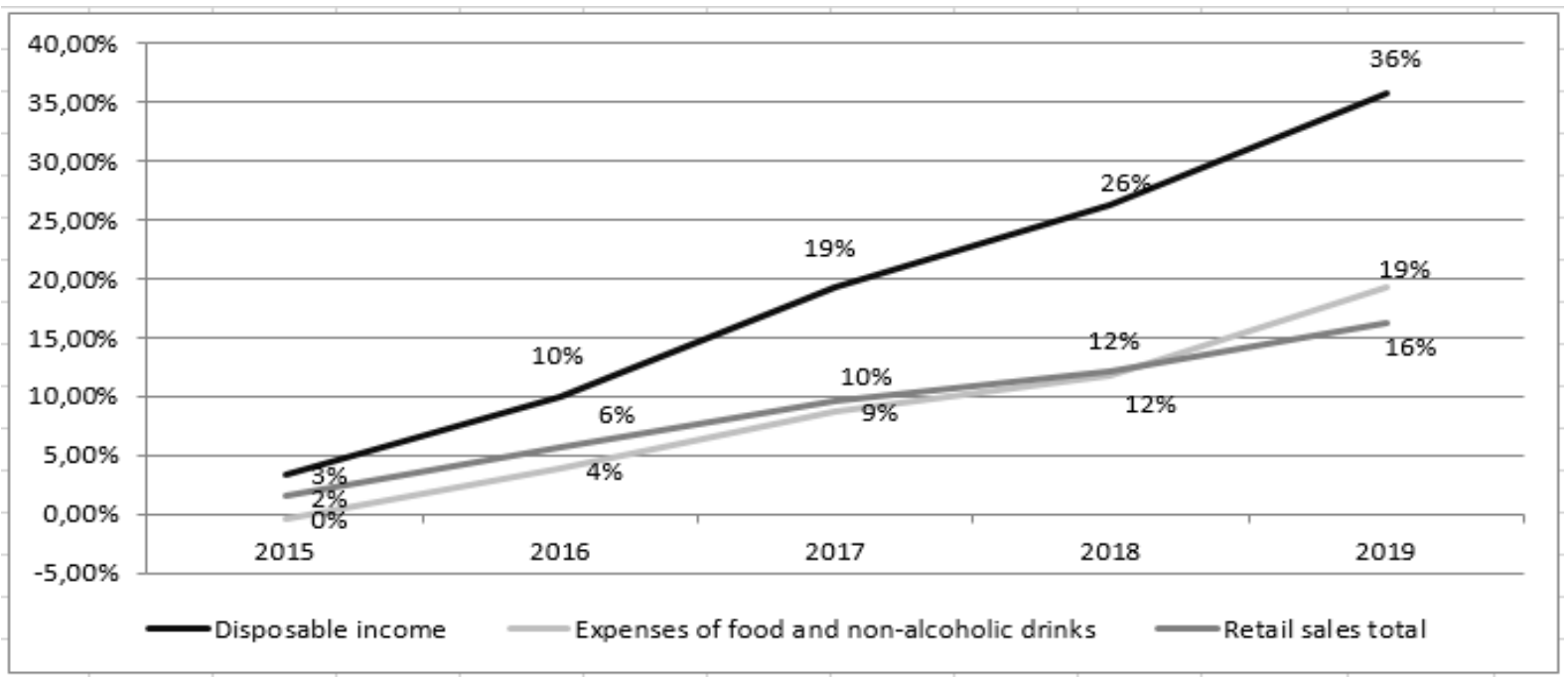

Figure 6. Dynamics of disposable income, food expenditure and retail sales of grocery stores in 2015-2019 (in 2014 prices). Source: own elaboration based on the research results.

The effect of dynamic income growth of less affluent social groups is to reduce the income gap, which is reflected in the declining level of both the Gini coefficient (from 30.6 in 2015 to 28.5 in 2019) and the quintile income ratio, analogously from 6.2 to 4.9. Given the much greater alignment of the quintile coefficient of food expenditure (1.6 in 2019), it can be concluded that, due to the limited differences between consumers of extreme income groups in this respect, their choices regarding the place of purchase of first-time products are similar. Such a statement is all the more justified because, in terms of the average level of disposable income per person, Poland is only in 28th place among European countries, and the level of this indicator is slightly higher than half of the European average. 
This means that the dominant part of Polish consumers has to manage their financial resources sparingly, which also applies to the acquisition of necessities (Mirońska, 2010, pp. 122-123). This is manifested in the search for products at attractive prices, promotions and price opportunities and acceptance of private labels as substitutes to more expensive branded products.

The moderate average annual increase in expenditure on necessities (CAGR 4.6\%) determines the rate of growth of the value retail market as a whole. The development of retail in the FMCG industry is derived from the market activity of individual retail chains, whose sales dynamics are higher than the growth rate of the whole market. At a higher level of aggregation, this is shaped by dynamic trading formats, in which market expansion exceeds the growth rate of the entire market. Due to demand constraints, the dynamic development of some retail networks (and stores formats) comes at the expense of other less competitive entities and commercial formats.

In the analyzed period 2015-2019, the inter-format structure of the food trade changed noticeably. This was mainly characterized by the strong development of the discounter chains, whose sales growth at that time was on average (CAGR) of $10.6 \%$ per annum. The wide and growing interest of customers in such stores is due to the optimal adaptation of the commercial offer to the expectations of customers of different levels of affluence. This includes convenient locations near where potential customers live, relevant in terms of sales space size, convenience and speed of shopping, affordable prices and the appropriate composition of the product assortment (Kucharska, 2016, p. 36). It includes offers at the economic and standard level, own brands and branded products, foodstuffs and selective offer of industrial products. Discount offers also include products tailored to the expectations of more demanding customers, e.g. premium, organic or vegan products (Borusiak, 2008, p. 99).

The overall increase in consumer wealth has also enabled the dynamic development of convenience networks (CAGR 8.1\%). These shops are most often located in opportune locations in large and medium-sized cities. The offer of these stores consists of a limited range of necessities, impulse offers and a diverse range of consumer services, including small gastronomy. This format generally addresses its commercial offer mainly to customers from higher income groups, and the price level is among the highest market ceilings. However, due to the low value of the shopping cart, customers in convenience stores are also less welloff customers, including young people leading an active lifestyle.

Supermarket stores reported a moderate 4.1\% CAGR increase in sales between 2015 and 2019. It should be emphasized that in this category of retail outlets there are both large-scale shops up to $2500 \mathrm{~m}^{2}$ as well as compact retail outlets of $300 \mathrm{~m}^{2}$ to $500 \mathrm{~m}^{2}$. This distinction is so important that Polish consumers clearly prefer proximity supermarkets, such as Dino, Stokrotka and Carrefour Market. In order to increase competitiveness, supermarket operators have used a number of solutions typical of discounters in their retail establishments, such as reducing the depth of the commodity range, introducing their own brands or executing intensive 
price promotions. These measures are aimed at generating the interest of the dominant part of Polish consumers, who combine quality expectations (in terms of products and place of purchase) with the expectation of affordable prices (Kłosiewicz-Górecka, 2013, p. 135). In this diverse format, smaller supermarket chains located in convenient locations, i.e. residential areas or smaller towns, are successful.

The networks in hypermarket format are in the phase of slight yet deepening regression. This phenomenon occurs despite the important advantages of these retail establishments, such as the lowest market prices and the widest product range. The reason for the limited consumer interest in these retail establishments is the desire of a growing number of consumers to convenience and reduce the time spent shopping for first-time products. Despite the relatively low prices, the specificity of shopping in large-scale stores is a larger "shopping basket", which is contrary to the concept of frequent but smaller grocery purchases in convenience stores and housing estate outlets. On the other hand, rising incomes mean that the argument of low affordable prices is considered by consumers together with other aspects of commercial activity, such as convenient location, saving time to shop or satisfactory commercial offer in shops close to where potential customers live (Ciechomski, 2018, pp. 67-68).

Development in dynamic trading formats takes place at the expense of small-format grocery stores. In the years 2015-2019, the decrease in sales of small-format stores was already only an average annual (CAGR) of $0.4 \%$. This is due to the failure to adopt some of these retail establishments to the increasing price and quality requirements of Polish consumers. Polish consumers have European purchasing aspirations with very limited (compared to Western European countries) income opportunities. Already in the first decade of the $21 \mathrm{st}$ century, the characteristic attitude of "smart shopping" for Polish consumers was revealed, which at the same time has a profit and aspirational basis (Sobczyk, 2013a, p. 340). This is reflected in the combination of requirements for quality products and shopping comfort with expectations of affordable, as low prices as possible.

Attention should be also paid to the increasing average area of stores in this format and to improving sales performance indicators. This indicates clear adaptive changes, mainly due to the connection of stores in this format to networks operating nationwide. Thanks to this, progress was made in terms of affordability, visualization of these establishments, quality of assortment or promotional activity (Kowalska, 2012, p. 142).

A characteristic feature of retail trade in Poland is intense competition in the framework of the multi-format structure. Operators in all formats have high adaptability to the current requirements of the Polish market. This applies primarily to the consideration of purchasing behaviour and preferences of Polish consumers, who are showing an increasingly equal level in spending on food and other necessities. Consequently, the operators of most retail chains seek to meet the expectations of the dominant part of Polish consumers, who combine highquality needs of products and outlets with the expectation of affordable prices. The principle of 
convergence manifested in these activities makes the shops of different concepts and formats similar on many levels (Kosińska-Gębska, Tul-Krzyszczuk, Gębski, 2011, p. 45).

\section{Comparative analysis of the impact of income on trade in the two provinces of Wielkopolskie and Podlaskie}

This paper also attempts to analyze the relationship between income factors and the structure of retail trade in the food industry in a spatial system, based on the example of two voivodeships: Wielkopolskie and Podlaskie. In terms of the disposable income, both regions present a similar level, in the case of the Wielkopolskie region by one-, and for the Podlaskie region by 4 percentage points lower than the national average. The demographic and income indicators are presented in Table 1.

Table 1.

Selected demographic and income indicators of the Wielkopolskie and Podlaskie voivodships (2019)

\begin{tabular}{|l|l|r|r|r|}
\hline Parameters & Units & Polska & Wielkopolskie & Podlaskie \\
\hline Population & people & 38382576 & 3498733 & 1178353 \\
\hline Surface & $\mathrm{km}^{2}$ & 312705 & 29826 & 20187 \\
\hline Density of population & Persons $/ 1 \mathrm{~km}^{2}$ & 123 & 117 & 58 \\
\hline Urbanization rate & \% & 60,5 & 55,2 & 60,3 \\
\hline Number of cities & units & 954 & 113 & 40 \\
\hline Number of cities over 20 000 residents & units & 218 & 20 & 8 \\
\hline Disposable income per person & PLN/month & 1819 & 1807 & 1742 \\
\hline Purchasing power/1 km ${ }^{2}$ & PLN mln/1 year & 2,68 & 2,54 & 1,22 \\
\hline Total expenses per person & PLN/1 month & 1252 & 1163 & 1030 \\
\hline $\begin{array}{l}\text { Expenditure on food and non-alcoholic drinks } \\
\text { per person }\end{array}$ & PLN/1 month & 314 & 297 & 320 \\
\hline $\begin{array}{l}\text { Share of food and non-alcoholic drink expenses. } \\
\text { in disposable income }\end{array}$ & \% & 17,3 & 16,4 & 18,4 \\
\hline $\begin{array}{l}\text { Purchasing potential of food and drinks without } \\
\text { alcohol/1 km }\end{array}$ & PLN ml/ 1 year & 0,46 & 0,42 & 0,22 \\
\hline
\end{tabular}

Source: own elaboration based on: Regiony Polski 2020, GUS, Budżety Gospodarstw domowych w 2019 r. GUS, Polska w liczbach. GUS, Bank danych Lokalnych, GUS, Rynek wewnętrzny 2019, GUS.

Figure 7 presents information on the amount of disposable income and expenditure on food and non-alcoholic beverages in 2019 in both of the above-mentioned voivodeships.

The distribution is different with regard to expenditure on food and soft drinks, which are $2 \%$ higher in Podlaskie and 6 percentage points lower than the national average in the Wielkopolskie region. This difference is due to the fact that in Podlaskie the share of food expenditure in disposable income is significantly higher at $18.4 \%$ compared to $16.4 \%$ in Wielkopolskie (Kuśmierczyk, 2006, p. 77). 
The two provinces differ significantly in terms of population and area; hence it is necessary to bring income parameters to the common denominator. On the basis of the population density index and the level of disposable income, purchasing power per unit area (in PLN million per 1 sq. $\mathrm{km}$ ) was determined. This rate is more than twice as high in the Wielkopolskie region, which is mainly the result of a correspondingly higher level of population density. Similarly, the purchasing potential per unit area for food and soft drinks can be determined, which in the Wielkopolskie region amounted to PLN 0.46 million per year compared to PLN 0.22 million in Podlaskie.

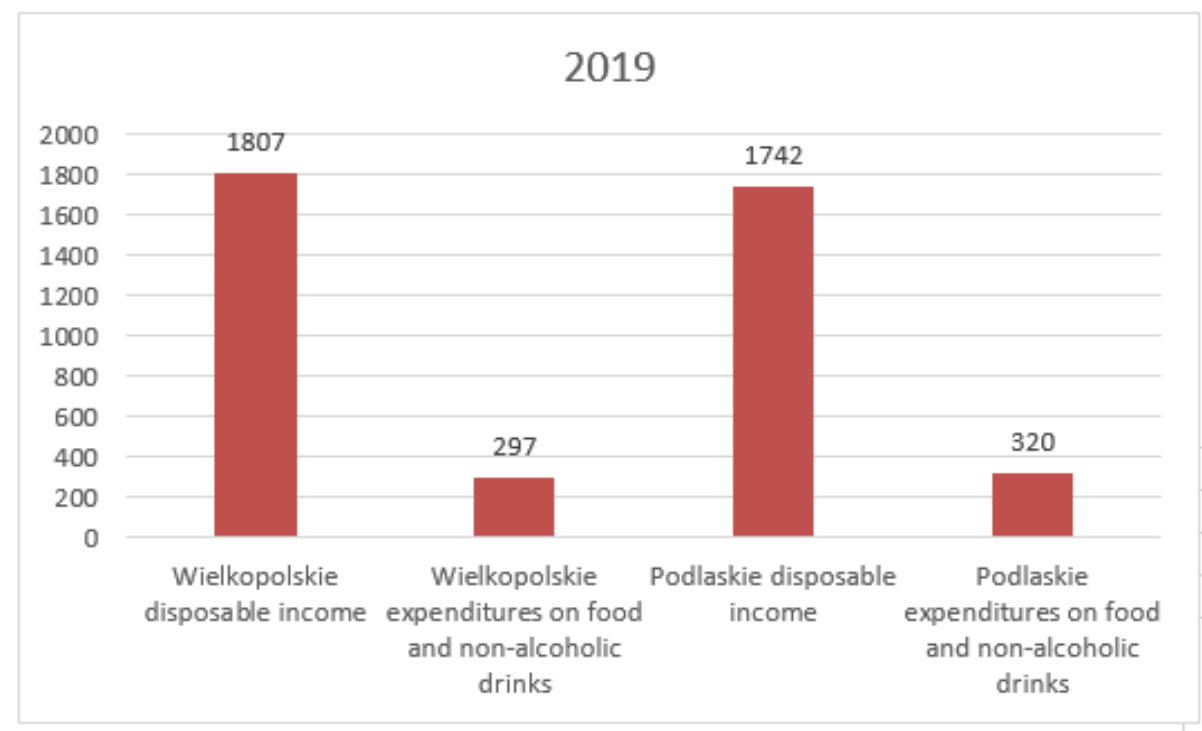

Figure 7. Disposable income and expenditure on food and soft drinks in the Wielkopolskie and Podlaskie voivodships in 2019. Source: own elaboration based on the research results.

The total number of grocery stores in 2019 in Wielkopolskie amounted to 8832, which is more than four times the number of stores in Podlaskie, where 2495 outlets were registered. Such a significant difference is mainly due to the larger area and a much higher population in Wielkopolskie. For the comparison purpose, the number of shops per sq. km was determined, which in the Wielkopolskie region was 0.30 compared with more than twice the density of the location in Podlaskie of just 0.12 store.

For the purpose of comparison, the location density was determined in the form of a parameter showing the number of $\mathrm{km}^{2}$ per one store. This indicator in the Wielkopolskie voivodship amounted to $3.6 \mathrm{~km}^{2}$, compared to the more than twice as high parameter in Podlaskie, amounting to $8.1 \mathrm{~km}^{2}$. Data on grocery stores in Wielkopolskie and Podlaskie voivodships are presented in Table 2 .

Much smaller disparities were in terms of comparing the number of shops per 10,000 inhabitants, which in Wielkopolskie was 25.2 , being by $12 \%$ higher than the national average. By contrast, in the Podlaskie region, this parameter was at the level of 21.2 store, which is by $6 \%$ lower than the indicator for the entire domestic market. 
Table 2.

Selected retail trade indicators in the Wielkopolskie and Podlaskie voivodships (2019)

\begin{tabular}{|l|l|r|r|r|}
\hline Parameters & Units & Polska & Wielkopolskie & Podlaskie \\
\hline Total number of stores & Units. & 333340 & 34042 & 9617 \\
\hline Number of grocery stores & Units. & 86482 & 8832 & 2495 \\
\hline Number of hypermarkets & Units. & 466 & 47 & 10 \\
\hline Number of supermarkets & Units. & 3506 & 406 & 98 \\
\hline Number of convenience stores & Units. & 6033 & 405 & 132 \\
\hline Number of discounters & Units. & 4240 & 317 & 111 \\
\hline Number of small-format grocery stores & Units. & 72237 & 7656 & 2144 \\
\hline Total grocery store location density & $\mathrm{km}^{2} / 1$ outlet & 3,6 & 3,4 & 8,1 \\
\hline Location density of hypermarkets & $\mathrm{km}^{2} / 1$ outlet & 671,0 & 634,6 & 2018,7 \\
\hline Location density of supermarkets & $\mathrm{km}^{2} / 1$ outlet & 89,2 & 73,4 & 207,0 \\
\hline Location density of convenience stores & $\mathrm{km}^{2} / 1$ outlet & 51,8 & 73,6 & 154,7 \\
\hline Location density of discounters & $\mathrm{km} / 1$ outlet & 73,8 & 94,1 & 181,7 \\
\hline Location density of s small-format grocery stores & $\mathrm{km}{ }^{2} / 1$ outlet & 4,3 & 3,9 & 9,4 \\
\hline Total number of grocery stores vs population & persons/1 outlet & 444 & 396 & 472 \\
\hline Total number of hypermarkets vs population & persons/1 outlet & 82366 & 74441 & 117836 \\
\hline Total number of supermarkets vs population & persons/1 outlet & 10948 & 8609 & 12083 \\
\hline Total number of convenience stores vs population & persons/1 outlet & 6362 & 8629 & 8914 \\
\hline Total number of discounters vs population & persons/1 outlet & 9052 & 11034 & 10604 \\
\hline $\begin{array}{l}\text { Total number of small-format grocery stores vs } \\
\text { population }\end{array}$ & persons/1 outlet & 531 & 457 & 550 \\
\hline Source: Own elaboration based on the research & & & \\
\hline
\end{tabular}

Source: Own elaboration based on the research results, Bank Danych Lokalnych, Rynek wewnętrzny w 2019 roku, Rocznik Statystyczny Województwa Wielkopolskiego, Raport o sytuacji społecznogospodarczej województwa podlaskiego 2020.

Given the slightly higher level of spending on food and soft drinks in the Podlaskie region, it is difficult to justify higher retail rates in the Wielkopolskie region. This means that other factors play an important role in the location of grocery stores. In this case, such a parameter can be the population density, which is twice as high in the Wielkopolskie region (Kondej, $2019 \mathrm{~b}$, p. 90). The number of square kilometers per one store is more than two times lower in Wielkopolskie, however, the difference between the two regions in terms of the number of people per store is only $19 \%$. On this basis, it can be concluded that, with a comparable level of income and expenditure on food, low population density is a factor hindering the development of retail chains. This may be related to greater difficulty in reaching more distant retail outlets, which may force consumers in rural areas to make less frequent purchases in advance.

It is also worth looking at the format structure of stores in both provinces. Figure 8 below presents the percentage structure of the share of each format of retail outlets in the sale of necessities. 


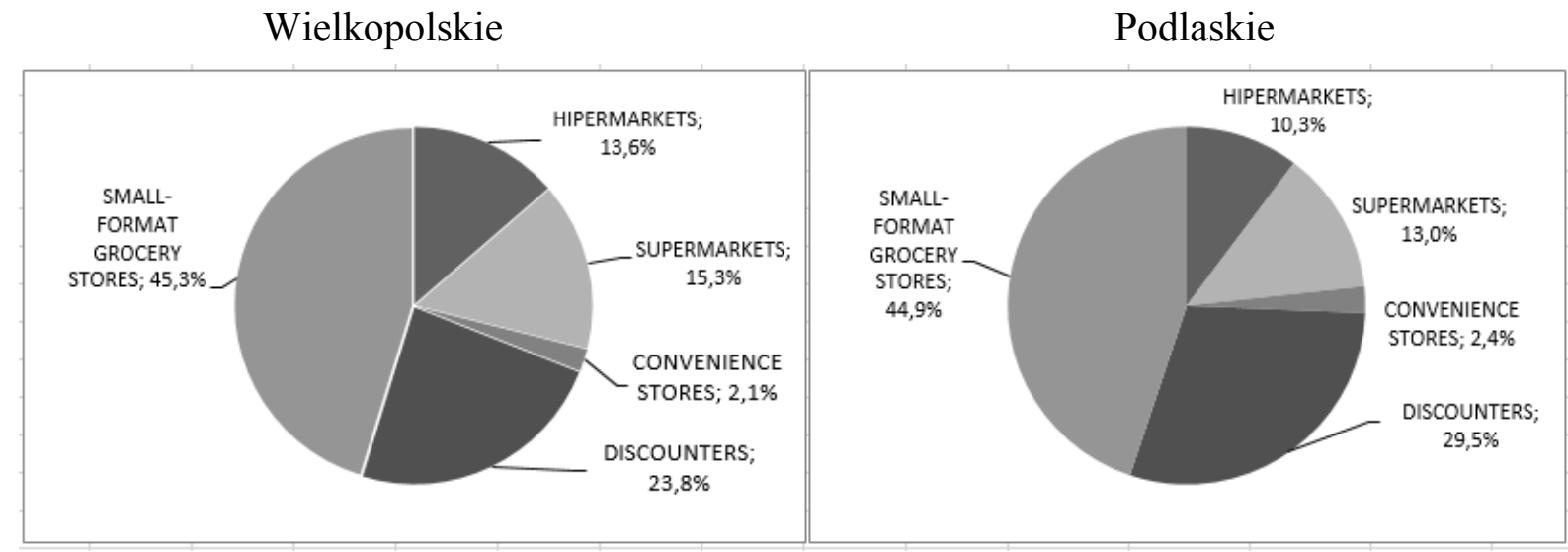

Figure 8. Value sales structure of food market formats in Wielkopolskie and Podlaskie provinces in 2019. Source: Own elaboration based on the research results.

It draws attention to the predominance of the Wielkopolskie region in the participation of chains treated as modern, i.e. hypermarkets and supermarkets. With relatively equal incomes, the causes of this phenomenon may be found in the greater share of large cities in this region, which provides the most convenient locations for stores from these formats. With a similar share of small-format stores and convenience, the advantage of the Podlaskie region amounts to a much larger share of the value structure of discount stores. This concerns the intensive expansion in the region of two discount chains, Biedronka and Lidl (Domański, 2001, pp. 110-111). The favorable factor for these chains is relatively lower competition from supermarkets and hypermarkets and an increasingly pronounced but still persistent price advantage over small-format stores. This is particularly true for independent small grocery stores, which are often unable to compete effectively with expansive discount stores.

In both compared voivodeships, there also exist the determinants not directly related to the demand, which plays a significant role in terms of store locations. These are factors such as the level of economic development of a given region, longer trade traditions, a more central location of many stores and the proximity of logistic warehouses, often located in the central part of the country. An example of a comparative analysis of these voivodeships clearly shows that the broadly understood total income factor has a moderate impact on the development and structure of retail trade. However, there is an impact of income diversification in terms of the size of the town, including the influence on the trade structure of large agglomeration, such as Poznan (Kaczmarek. 2010, p. 146). The comparative analysis confirms that the dominant influence on the location of grocery stores is the population density. Thus, the real demand potential for commercial operators is the combination of income and expenditure on food with population density. For this reason, in the Podlaskie region, which is characterized by the lowest population per unit area in the country, there is a more dispersed structure of retail trade than in the more populated Wielkopolskie Voivodeship. 


\section{Conclusions}

The analyzes show that income factors exert a comprehensive but not directly impact on the situation in retail trade. There is no doubt that the steady long-term increase in consumer income is the basis for the development of commercial enterprises. However, this has a greater impact on the product structure of consumption, and only to a limited extent on the choice of the place of purchase in these categories. The key impact factor is the declining income inequality, which is mainly due to a marked increase in the financial capacity of groups with a lower level of affluence. This affects the levelling of expenses on food and non-alcoholic beverages, as a result of which the influence of the income factor on the choice of the place of purchase becomes limited. Although consumers from different income groups have different quality expectations, they can be realized in many different grocery stores. Despite the steady increase in the level of affluence, the vast majority of Polish consumers still combine quality requirements with restrictions on household budgets. As a consequence, it favours the formation of a multi-format structure in retail trade in Poland, as various stores are able to meet the needs of the majority of Polish consumers.

In this situation, market successes on a national scale can be achieved by retail chains that address their offer to wider social groups and those in which quality and price are best combined, taking into account current consumer trends as well as the current expectations and needs of buyers (Kucharska, 2014, pp. 221-223). The beneficiaries of these transformations are mainly: discount stores, chain medium and large grocery stores, compact proximity supermarkets, and convenience stores (in large and medium cities).

On the other hand, income conditions negatively affect small independent grocery stores, which are not competitive to larger retail chains in terms of assortment, price and convenience of shopping for customers. Consumer trends resulting from the growing financial possibilities of consumers are also not conducive to the functioning of hypermarkets, because a significant part of consumers is driven by factors such as convenient store locations, speed of shopping or attractive promotional campaigns (Ciechomski, 2018, pp. 67-68).

\section{References}

1. Bank Danych Lokalnych (2021). Główny Urząd Statystyczny, www.bdl.stat.gov.pl, 2.02.2021.

2. Borusiak, B. (2008). Modele wzrostu przedsiębiorstw handlu detalicznego. Poznań: Akademia Ekonomiczna. 
3. Budzety gospodarstw domowych w 2019 r. (2020). Warszawa: Główny Urząd Statystyczny, https://stat.gov.pl/, 15.01.2021.

4. Ciechomski, W. (2010). Koncentracja handlu w Polsce i jej implikacje dla strategii konkurowania przedsiębiorstw handlowych. Poznań: Wydawnictwo Uniwersytetu Ekonomicznego.

5. Ciechomski, W. (2018). Współczesne trendy zachowań konsumentów a sukces marek handlowych. Handel Wewnętrzny, no. 6, tom 2. Poznań: Instytut Badań Rynku, Konsumpcji i Koniunktur.

6. Domański, T. (2001). Strategie marketingowe dużych sieci handlowych. Warszawa-Łódź: PWN.

7. Gardocka-Jałowiec, A. (2015). Zmiany konsumpcji a kreowanie innowacji. Białystok: Wydawnictwo Uniwersytetu w Białymstoku.

8. Kaczmarek, T. (2010). Struktura przestrzenna handlu detalicznego. Poznań: Bogucki Wydawnictwo Naukowe.

9. Kłosiewicz-Górecka, U. (2013). Struktura handlu detalicznego w Polsce a preferowane przez konsumentów miejsca zakupu FMCG. Konsumpcja i Rozwój, no. 2(5). Warszawa.

10. Kondej, A. (2017). Wpływ zróżnicowania dochodów konsumentów na rozwój przedsiębiorstw handlowych branży FMCG (Fast Moving Consumer Goods) w Polsce. Praca doktorska. Białystok: Uniwersytet w Białymstoku.

11. Kondej, A. (2019). Transformacja handlu detalicznego Fast Moving Consumer Goods (FMCG) w Polsce po 1989 roku. Annales Ethics in Economic Life, Vol. 22, No. 1. Łódź: Wydawnictwo Uniwersytetu Łódzkiego.

12. Kosińska-Gębska, M., Tul-Krzyszczuk, A., \& Gębski, J. (2011). Handel detaliczny żywnościq w Polsce. Warszawa: Wydawnictwo SGGW.

13. Kowalska, K. (2012). Rozwój polskich sieci detalicznych jako sposób ograniczania sity rynkowej międzynarodowych korporacji handlowych. Warszawa: Difin.

14. Kucharska, B. (2014). Trendy w zachowaniach konsumentów jako uwarunkowanie innowacji w handlu detalicznym. Studia Ekonomiczne, no. 187. Katowice: Uniwersytet Ekonomiczny.

15. Kucharska, B. (2016). Ewolucja formatów jako przejaw innowacyjności przedsiębiorstw handlowych w Polsce. In: M. Sławińska (ed.), Handel we współczesnej gospodarce. Nowe wyzwania. Poznań: Katedra Handlu i Marketingu, Uniwersytet Ekonomiczny.

16. Kuśmierczyk, K., Piskiewicz, L., Szepieniec-Puchalska, D. (2006). Przestrzenne zróżnicowanie konsumpcji w Polsce. Warszawa: Instytut Rynku Wewnętrznego i Konsumpcji.

17. Liczmańska, K. (2015). Kluczowe czynniki determinujące zachowania konsumenckie na przykładzie mieszkańców województwa kujawsko-pomorskiego. Zeszyty Naukowe Uniwersytetu Szczecińskiego, No. 41, t. 2. Szczecin. 
18. Mirońska, D. (2010). Zachowania konsumentów na rynku - trendy i wpływ na działania przedsiębiorstw. Zeszyty Naukowe, no. 27. Warszawa: Szkoła Główna Handlowa.

19. Rynek wewnętrzny w 2019 roku (2020). Warszawa: Główny Urząd Statystyczny.

20. Sobczyk, G. (2013), Zachowania konsumenckie w warunkach kryzysu (na przykładzie województwa lubelskiego). Zeszyty Naukowe Wyższej Szkoły Ekonomii i Innowacji w Lublinie, no. 1 .

21. Sobczyk, G. (2018). Zachowania konsumentów wobec nowych trendów konsumpcji wyniki badań. Annales Universitatis Mariae Curie-Skłodowska. Oeconomica, 52(1). Lublin. 